\title{
THE CONTRIBUTION OF A PRIVATE HIGHER EDUCATION INSTITUTION TO THE SOUTH AFRICAN HIGHER EDUCATION LANDSCAPE
}

\section{N. Tankou epse Nukunah}

Masters Student: University of South Africa

e-mail: chimene@milpark.ac.za

\section{A. Bezuidenhout ${ }^{\star}$}

e-mail: bezuia@unisa.ac.za

\section{A. Furtak*}

e-mail: hyraam@unisa.ac.za

*Department of Human Resources Management

University of South Africa

Pretoria, South Africa

\section{ABSTRACT}

Private Higher Education (PHE) is perceived in South Africa to deliver programmes of questionable quality in search of profit maximisation (CHE 2016, 84). To curb this perception, the Council on Higher Education ( $\mathrm{CHE}$ ) has instituted strict regulations with regard to accrediting qualifications presented by institutions of higher learning. To determine the contributions of PHE to the South African higher education landscape, this article evaluates a registered management programme, recommended by the Higher Education Quality Committee (HEQC) of the CHE, and the South African Qualifications Authority (SAQA) (CHE, 2013). Using Kirkpatrick's (1996) fourlevel model of training programme evaluation as the theoretical framework, the management programme was evaluated to determine its contribution to the South African higher education landscape. The four levels included the perception of the learners, the knowledge gained by the learners, the learners' performance in the workplace and the return on investment. Other stakeholders, such as the sponsors and students' line managers, were interviewed to determine whether the programme had contributed to work outputs. Overall, the results show that the programme is contributing to the development of higher education in South Africa.

Keywords: Council on Higher Education, evaluation, Kirkpatrick's Four-Level Model, management programme, private higher education, South African Qualifications Authority, students

\section{INTRODUCTION}

The apparent mistrust surrounding Private Higher Education Institutions (PHEIs) in South 
Africa is concomitant to the belief that they are "entrepreneurial" in nature, mainly seeking profit for their stakeholders (Van Schalkwyk 2011, 32). However, Bezuidenhout $(2012,59)$ and Field and Shah (2016, xxiii) suggest that the increase in PHEIs, especially in developing countries, is seemingly driven by demand absorption. The global massification of higher education (HE) has led to needs that governments cannot meet. Mohamedbhai (2008, vi) defines massification as the unavoidable experience by higher education institutions (HEIs) of a quick upsurge in student enrolments. Both public and private institutions have experienced a rise in student admissions without an accompanying surge in the different types of resources. This has had significant influence on these organisations's quality of teaching and learning, the standard of living of the students and the physical infrastructure (Mohamedbhai 2008, vi). Massification became prevalent between 2000 and 2010 when higher institutions in Africa experienced an upsurge in enrolments by 50 per cent that is, from $2.3 \mathrm{~m}$ to $5.2 \mathrm{~m}$ within one decade (Africa-America Institute, 2015). This growth can be explained partly by the belief that the number of students enrolled in university education is a measure of development, and that it is an attempt to meet skill gaps even when most university programmes are not market-driven (Ngware 2016, 203). The concept of massification relates not only to an increase in enrolments, but to a number of other associated changes: the make-up of the students; curricula and qualifications; the broad range of qualifications offered; the launch of several entry and exit points within the HE system; and shifts in the vision and mission or these institutions.

As part of its offering of tertiary education and training, the Department of Higher Education and Training (DHET) strives to encourage the delivery of vital skills required to improve the economy and social status of the people of South Africa (DHET 2014, 1). Despite the scepticism around PHEIs, they serve as a conduit to meet skill shortages in the workplace. This article uses Kirkpatrick's four-level model to evaluate a management programme run in the South African banking sector to determine whether the training intervention has contributed to skills development in the sector. Kirkpatrick's four-level model of training programme evaluation, evaluating reaction, learning, behaviour and results, is widely acknowledged and adopted to measure the success of a training programme (Rajeev, Madan and Jayarajan 2009, 272). This approach focuses on four aspects of the training intervention. Firstly, the reaction level measures how the students perceive the programme. Secondly, the learning level assesses how much knowledge the student has gained from the training programme through tests and examinations. Thirdly, the behaviour level measures whether the training has influenced the student's behaviour. The level is determined by observing the student's performance while on the job in the application of the skills obtained from the programme. Finally, results analyse the outcome of the training programme and its impact on the organisation and other stakeholders 
(Kirkpatrick 1996, 55-56).

The qualification used on the programme is currently registered with the CHE and SAQA and is offered by a PHEI in South Africa. The Certificate in Management Development (CMD) is registered on the National Qualifications Framework (NQF) Level 5 (SAQA ID 62269). The qualification is aimed at supervisors and newly appointed managers or persons aspiring to be appointed at a managerial level. This article therefore argues that PHEIs contribute significantly to HE training in South Africa, by offering quality, holistic learning programmes.

To provide context to HE both locally and internationally, the next section discusses HE by examining the global private provision landscape. Thereafter, an exploration into both HE in South Africa as a whole and into PHE in South Africa is undertaken.

\section{A GLOBAL PERSPECTIVE OF PRIVATE HIGHER EDUCATION}

The importance of PHEIs globally, and in South Africa, seems definite. According to Setswe $(2013,98)$, the global market for post-school education has skyrocketed since the late 1980s at an average rate of 7 per cent per annum. Universally, there has been more than 80 million postschool students and an additional 3.5 million employed students pursuing their studies at an institution of higher learning. The yearly income generated from tuition fees is approximately over US $\$ 30$ billion, with the majority from private institutions. A plethora of studies have been documented in the literature of a considerable increase in private higher-education offerings worldwide (Dlamini 2016, 58; Teixeira et al. 2012, 685; Zain, Jan and Ibrahim 2013, 78). Van Schalkwyk $(2011,32)$ agrees, suggesting that the private sector is so large in certain countries that it could potentially meet the need for HE on its own. The continual growth and expansion of PHEIs, has contributed in promoting the role it plays in the education sector globally. The increase in demand for education and favourable policies has pushed student numbers upward worldwide. Another factor that has contributed to the rise of PHEIs globally has been the perception people have about these institutions (Teixeira et al. 2017, 14). Moreover, a HE degree is viewed by many as a smart move towards personal growth and marketability, as shown by an insistent high rate of return, evident in most countries, especially in South Africa (Branson, Leibbrandt and Zuze 2009, 2). For many years, the perception among many communities has been that HE graduates are more likely to be employed with prospects of longterm income, as opposed to individuals with no tertiary qualification. In South Africa, people with a tertiary qualification expect to find a job without difficulty and to be paid more by their employer (Baldry 2016, 790; Branson, Leibbrandt and Zuze 2009, 2). A post-school qualification makes it more probable to find salaried employment and in some cases earning a higher salary. The degree to which tertiary education supports access to the labour market and 
level of earnings has increased over time (Branson, Leibbrandt and Zuze 2009, 16). The benefits derived from HE qualifications have contributed to the rise in demand especially in developing economies where a scarcity in skilled labour has resulted in an increase in the cost of these workers (Psacharopoulos and Patrinos 2002). The growth of private providers in HE, especially in developing countries, is seemingly driven by demand absorption (massification); against a background of financial limitations (Teixeira et al. 2012, 687).

However, the emergence of PHE worldwide has been applauded by many and seen as an opportunity to increase competition in the sector thus, improving the quality of programmes offered (Teixeira et al. 2017, 16). The persistent high demand for HE qualifications and the dynamic labour market has led to an intricate system where institutions are constantly developing new programmes to meet the needs of the market (Teixeira et al. 2017, 14). In line with this, South African public universities have developed a niche by creating business schools offering specialised programmes to meet the needs of students as well as companies. The aim of these business schools is to develop close links with industry to provide specific programmes so as to meet business needs. The increased demand to develop and equip employed professionals in the workplace has created a large market, in which private business schools also compete favourably.

Despite the upsurge in PHEIs worldwide, concerns over the quality of the programmes offered by these institutions has bolstered demand for government and regulatory bodies to install quality-assurance policies (Teixeira et al. 2017, xi). In countries with high numbers of low-income earners, an increase in PHEIs has raised the issue of equality; as access to these institutions has been limited to certain social classes in the community. The issue of global funding for HE has become a major concern, given the financial limitations faced by people in the community (Teixeira et al. 2017, 16).

Bernasconi $(2006,304)$ provides an alternative view and argues that PHEIs have brought about diversity in $\mathrm{HE}$ in the areas of funding, regulation, objective and extent of function. This author expounds that, overall, these institutions have lesser financial resources than public institutions. As a result, the governance of private institutions are more stringent, less liberal and reactive to a limited range of stakeholders that are free from public influence. Their mission is focused on meeting specific needs, niches and customer service. The programmes offered by PHEIs are grouped around a small number of study fields as opposed to public institutions, allowing tailor-made programmes to meet the needs of corporate organisations (Bernasconi 2006, 304). It is from this perspective that this article highlights the contribution of PHEIs to the South African HE landscape. 


\section{SOUTH AFRICAN HIGHER EDUCATION}

In 2016, the HE environment in South Africa consisted of 26 public universities, while PHEIs constituted 94 registered institutions and 31 provisionally registered institutions (CHE 2016). As with many other sectors in South African society, the development of the HE landscape has been significantly influenced by racial segregation. Prior to the abolition of apartheid in 1994, government policies in South Africa were reviewed to align with the new dispensation. In the education sector, the changes began with the appointment of the National Commission on Higher Education (NCHE). The aim of this commission was to design a policy that will revolutionise South Africa's HE sector. This gave birth to the Higher Education Act, No. 101 of 1997. The current national HE framework is therefore designed to address inequalities and ineffective delivery that resulted from a disjointed educational system divided along racial lines before 1994 (Bezuidenhout 2013, 20-21). The post-Apartheid HE landscape has consequently undergone in-depth institutional and regulatory change (Davis 2013, 167).

The HE sector in South Africa is governed by a set rules and policies on which decisions are made and executed. Despite numerous changes made to the HE process prior to 1994, Hay and Monnapula-Mapesela (2009) postulate that the South African HE environment is still plagued with many issues. Some of these issues comprise of persistent inequality (along racial lines) with regard to access; ineffective throughput rates; decreasing funds; the inability to handle an upsurge in HE demand; the uneven quality of teaching and learning; qualification structures that makes movement between institutions difficult; misalignment of programmes offered; dynamic market with diverse needs; poor research output; and shortage of staff (CHE 2016, 9; Nzimande 2009).

In an attempt to cater to the upsurge in the demand of HE in South Africa, expansion and differentiation in the HE system is necessary (DHET 2013, 1-3). DHET (2016a, 1-3) further recognises the need to review strategies to ensure quality delivery of HE. SA News (2016) reports that Dr Blade Nzimande, the South African Minister of Higher Education and Training, expressed his concern over the severe lack of academics in a growing South African HE landscape. Nzimande stated that 1200 new academics need to be recruited every year to address the HE needs in South Africa. According to Faber and Collins (2016), South Africa could also see an exit of skilled academics following the 2015/2016 student protests.

Wangenge-Ouma $(2012,836)$ states that finance is the primary factor that determines entry to HE in South Africa. The issues surrounding funding of HE at present is deplorable, with a steady decline in government sponsorship, yearly fee increases, and insufficient support from the National Student Financial Aid Scheme (NSFAS). These challenges have made it difficult especially for low-income earners to have access to these institutions thus, widening 
the gap between the "haves" and the "have not". It is therefore safe to say that the recent demand by students in HE institutions for free education can be linked to scarcity of funding. The recent "Fees Must Fall" protest, triggered by limited access to HE tuition fees and limited subsidised space at public providers amidst a pressing demand for HE, emphasises the challenges around funding. It is interesting to note that there were no notable protests at any of the numerous private HE providers across South Africa.

\section{PRIVATE HIGHER EDUCATION IN SOUTH AFRICA}

DHET $(2013 ; 2016)$ reported an increase in private HE enrolments of 59.9 per cent from 90767 in 2010, to a head count of 144210 learners at 124 private HE providers in 2015. In comparison, 2015 saw 985212 enrolments at 26 public universities. This represents an increase of 10.3 per cent in the public sector. The private HE enrolment growth rate is considerably higher than public HE enrolments, with the private cohort representing 14.6 per cent of total HE enrolments. In 2016, there were 94 registered and 31 provisionally registered private HE providers (organisations that offer whole qualifications from NQF levels 5 to 10) (DHET 2016b). The tragic events at the University of Johannesburg in January 2012, where one parent died and over 80000 applicants contended for roughly 11000 places for first-year studies, are indicative of a serious desperation for good-quality HE in South Africa. This could be why many parents are starting to consider PHE as an alternative for their children's education (Setswe 2013, 101). The lack of space (80 000 applicants versus 11000 places) is another reason that students are studying at PHEIs. Although the public contingent is still significantly larger in terms of enrolment figures, the private-provision cohort in South Africa is growing.

To be eligible for registration as a private provider and thus to be able to legally present HE programmes in South Africa, a provider needs to adhere to the following regulations (DHET 2016b, 6):

- Be registered as a company in accordance with the Companies Act

- Comparable to its public counterparts, perform the roles of registering students for HE qualifications (on NQF levels 5-10), providing and delivering curricula, assessing students and awarding qualifications.

DHET $(2016 b, 6)$ argues that the registration of legal private providers ensures the delivery of quality qualifications, and that transformation goals are upheld.

The entrance of private providers into the sector has helped reduce the pressure in meeting the demand for HE. However, these institutions are confronted with numerous challenges, such 
as a lack of diversification, quality concerns and suspicion, as well as financing concerns. Teixeira et al. $(2012,686)$ suggest that this sector tends to focus only on a few disciplines. He continues to expound that not only are there fewer disciplines in PHE, these disciplines are mostly business and management oriented. Other challenges that have been identified are high fees and poor quality. Furthermore, increased competition in the HE marketplace, due to the large number of private providers entering the scene, has caused many to question the reliability of these institutions (Setswe 2013, 100).

In view of these concerns, however, students still choose to study at private institutions in South Africa. The answer to this may involve more than the demand absorption of students who failed to qualify at public universities. Finn (2013) is of the view that private providers are more client-oriented, flexible and supportive than their public counterparts; and they offer a safe environment. Baumgardt (2013, 113), however, disagrees and suggests that public providers expect less from students and provide a less challenging learning environment to students. They promote less collaborative learning, have less student-lecturer interaction, exhibit lower student-satisfaction ratings and offer less support to students. Although opinions differ, the Caerus Capital investment report on PHE investment opportunities (2017) states that potential competitive advantage for PHE providers in South Africa includes high student satisfaction, superior levels of student support, smaller classes with more student-lecturer interaction, and flexible and innovative learning options. Private providers are also renowned for higher qualification completion rates, diversification into various targeted (niche) programme offerings, business-like operational structures that promote effectiveness and efficiency, and agility in making and implementing strategic decisions; for example, innovation in teaching and the development of new qualifications. Their business-like nature and their clientorientation are representative of this competitive advantage.

\section{INTEGRATION OF PHEIS INTO THE WORKPLACE}

According to Wait and Govender (2016, 290), Workplace Integrated Learning (WIL) has become vital in the development of academic curricula. A number of government initiatives, namely South Africa's National Development Plan, the Work Integrated Learning - Good Practice Guide, the Green Paper for Post School Education, and the triple helix partnership imperative, has stirred educators, government and business to encourage effective WIL management and leadership. Dyer (2003) expounds on the notion, maintaining that the integration of different academic fields, the combination of several branches of learning and cross-disciplinary approaches is proposed for contact and on-the-job learning, as they enhance the overall learning experience for students. South Africa's HEQC $(2004,26)$ defines WIL as follows: 
“... the component of a learning programme that focuses on the application of learning in an authentic learning workplace context under the supervision and/or mentorship of a person/s representing the workplace. It addresses specific competencies identified for the acquisition of a qualification that makes the learner employable and assists in the development of related personal attributes. Workplace/service employees and professional bodies are involved in the assessment of the learning experience, together with university academic employees."

When managing WIL, there is a great reliance on four major contributors - the educator, the learner, the government and business - who are required to think strategically for successful implementation (World Bank Group 2012). Students seek direct involvement and knowledge to increase their chances for employment in a very dynamic environment. On the other hand, educators strive to produce graduates that are employable and that have the right skills, knowledge and values to meet the needs of the market. Businesses improve their learning capacity in order to maintain their competitive advantage and to be innovative in today's rapidly changing business environment (Laeeque, Babar and Ahmad 2017, 180). Finally, government aims to grow the economy, offset the skewed skills supply-demand statistics, mitigate the scarce and critical skills shortages and solve the challenges of unemployment, poverty and inequality (World Bank Group 2012).

Laeeque, Babar and Ahmad (2017, 180) suggest that organisations should conduct seminars and workshops to emphasise the importance of learning at both the organisational and individual level. Employees should be given training on issues associated with the adoption of learning-organisation practices. They believe managers should also be provided with training to determine how to design jobs and workstations so that employees can freely interact with coworkers and share, acquire, combine and apply knowledge. By nurturing a learning culture, the advantages to the organisation include an increase in the value of their human capital, a higher problem-solving ability, higher employee satisfaction and a reduction of risks within decisionmaking processes (Luhn 2016, 11).

To expand their competitive advantage, PHEIs have diversified their teaching methodologies to cater to the needs of government institutions, such as those of the Bankseta. The South African government established the Sector Education and Training Authority (SETA) to address the skills shortage in South Africa. In the banking sector, an industry-specific SETA was established, known as the Bankseta. The Bankseta aims to support transformation and people development within the banking industry through partnerships and to enable stakeholders to advance the national and global position of the broader banking industry (Badenhorst-Weiss et al. 2012, 342-344). One of the mandates of the Bankseta is to offer skills programmes in the banking sector. The Skills Development Department in the 
Bankseta implements a number of initiatives that support Junior and Middle Management, Occupationally Directed Qualifications, Executive Courses and International Executive Development Programmes (Bankseta 2017).

The CMD qualification is a SAQA-registered qualification at NQF Level 5 with 120 credits, offered to junior- and middle-level managers in the banking sector, in collaboration with a training provider. The qualification allows students to articulate to an NQF Level 6 Advanced Certificate, or even a Bachelor's degree. Kirkpatrick's four-level model of reaction, learning, behaviour and results was used to evaluate the programme from various points of view to determine students' perceptions, their increase in knowledge, their ability to apply on-thejob learning and the impact of the programme on the organisation. The theoretical framework used to evaluate this programme investigated the accuracy of the perception that PHEIs in South Africa are involved in questionable practices. The training provider that was appointed by the Bankseta to deliver the course is a PHEI currently registered with DHET in South Africa. The training provider was appointed by the Bankseta as the most appropriate and accredited training institution to deliver the management programme, due to its strong presence in the banking sector, as well as its experience in delivering similar programmes. The following section will look at the methodology that was used to determine whether the programme was beneficial to the sector and whether it met the aim of DHET: to increase the rate at which the key skills necessary for economic growth and social development are delivered.

\section{METHOD}

The research made use of a mixed-method design, which allowed the researchers to use quantitative and qualitative data-collection methods simultaneously (Creswell and Plano Clark 2011, 5). This methodology was appropriate as it generated a multi-faceted understanding of the views of different stakeholders on the programme. The quantitative phase comprised the use of two different instruments for data collection. Firstly, a questionnaire was used to explore students' perceptions of the management programme. Secondly, to determine whether learning took place, test scores were obtained from the training provider's database of four of the six modules completed on the programme. These test scores included class tests, consisting of twenty multiple-choice questions, an assignment and an invigilated examination. In the qualitative phase of the study, semi-structured interviews were conducted, firstly with skills development officers (SDOs) from various banks, to determine whether there was a change in behaviour of the participants in the workplace, and secondly with Bankseta staff members to measure the results of the programme in the organisation.

In terms of the quantitative phase of the study, 202 students were invited to complete the 
questionnaire. A total of 171 completed the questionnaire with a response rate of 82 per cent. The high response rate contributed to the validity of the data. The questionnaire consisted of two main sections, measuring internal and external dimensions. The internal dimension sought feedback from the participants on the relevance of the course, the quality of the training material and the aptitude of the facilitators on the programme. The external dimension examined the appropriateness of the venues and safety-related aspects.

\section{Findings}

\section{Results of the learners' perception measurement}

An analysis of the weighted average of all responses across all 29 questions is presented in Figure 1.

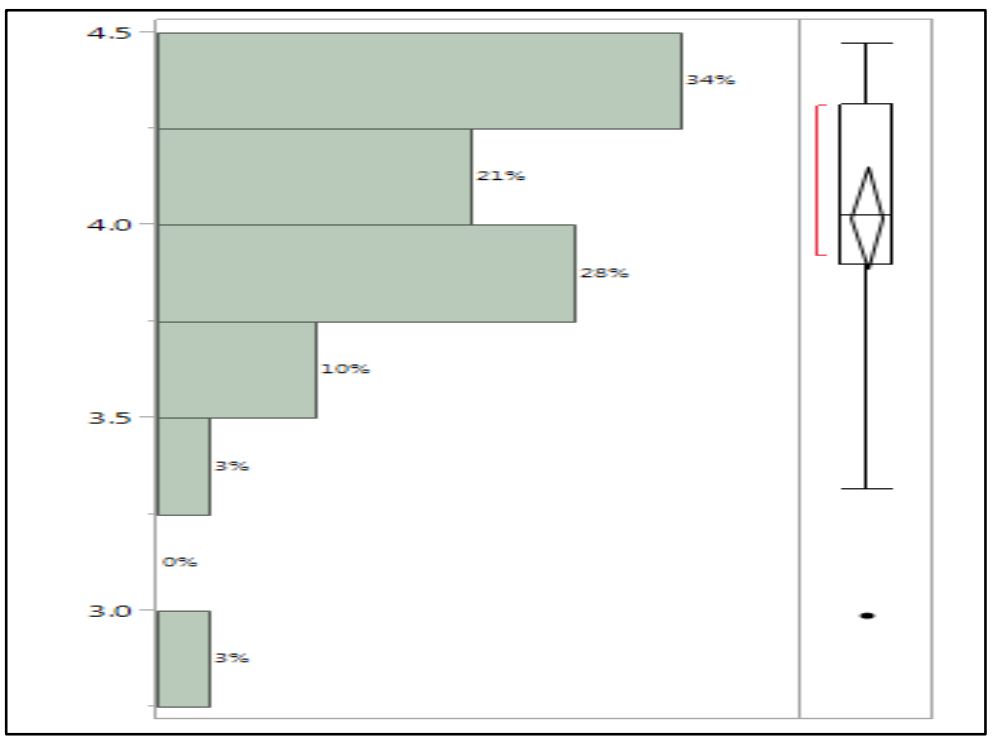

Figure 1: Summary of all responses in the internal and external dimensions

The average response to all questions asked was 4. Based on a weighted-average calculation, the standard deviation was 0.35 , which implies that there were very few responses that deviated from "4 - Agree". All questions presented a statement pertaining to the factors that would have an influence on the learning experience. $\operatorname{Kolb}(2015,51)$ defines learning as "the process whereby knowledge is created through the transformation of experience". He is of the view that knowledge is created from the combination of grasping and transforming experience.

If a student responded with option 4 , it indicated an agreement or positive experience with the factor under consideration. With option 4 being the average response, it can be deduced that, in general, students experienced the course positively. The dot in Figure 1 represents 
outlier responses - responses that are clustered outside the boundaries of a 95 per cent confidence interval around the average. A summary of the descriptive results is provided in Table 1 below.

Table 1: Numerical distribution of all responses to the internal and external dimensions

\begin{tabular}{|l|l|}
\hline Mean & 4.0191852 \\
\hline Standard deviation & 0.3489732 \\
\hline Standard error mean & 0.0648027 \\
\hline Upper 95\% mean & 4.1519275 \\
\hline Lower 95\% mean & 3.8864429 \\
\hline $\mathrm{N}$ & 29 \\
\hline
\end{tabular}

The skewness of the overall data was calculated at 1.12. This represents a negatively skewed bell shape, indicating that most responses were clustered around "Agree". There were a few responses that leaned towards " 2 - Disagree". There were also a few responses that leaned towards "1 - Strongly disagree". The outlier responses necessitate a further analysis to determine the reason for the negative response with regard to question B24 ("There is enough parking at the venue"). A closer analysis revealed that question B24 contributed towards the outlier value and is therefore considered the worst-performing variable. This factor scored an overall weighted average of 2.99. Two other questions, also in the external sub-dimension category scored low, but do not fall in the outlier category. These questions were "The chairs in the classroom are comfortable", which had a weighted average of 3.32, and "The classroom temperature is appropriate", which had a weighted average of 3.55. These findings result in the venue (an external sub-dimension category) being perceived as the least positive in the learning experience, with an overall score of 3.60 for the variables clustered in this category.

\section{Results of the knowledge-increase measurement}

The second part of the quantitative analysis entailed measuring learning by analysing the students' test scores on four modules. The modules analysed were Management and Leadership (MAL), Financial Management (FIN), Marketing Management (MKT) and Human Resource Management (HRM). The qualification average for the 200 students who were analysed was calculated to be 59.74 per cent, with a reasonable normal distribution and a standard deviation of about 9.68 per cent. The pass rate on the programme was set at 50 per cent and above. There were a number of outlier-performing students at both the top end, above 80 per cent, and the lower end of 45 per cent. Based on the distribution, the average performance was above 50 per 
cent. The pass rate was therefore high and most students passed the course. Figure 2 provides a comparison between the final qualification mark (the average of all the subjects) and the final marks for each module, showing that the strongest correlation exists with the MAL module, which had a correlation coefficient of 83.38 per cent.

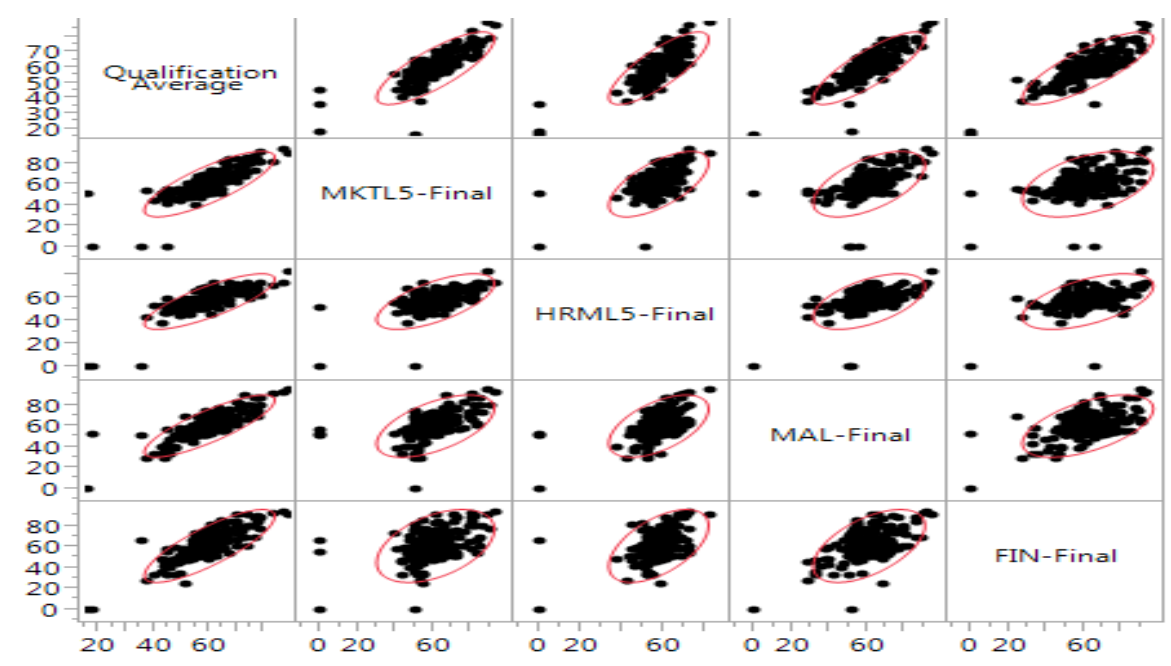

Figure 2: Result distribution between final qualification mark and the final marks for each module

The scatter plot, which shows a comparison of each of the assessments, in order of occurrence, from test, assignment and exam to the final mark for each of the modules, was analysed. A strong correlation between the exam mark and the final mark provided evidence that learning took place. There was no evidence that the poor perception of the parking impacted negatively on the test scores.

\section{Investigation of change in workplace behaviour}

In the qualitative phase, semi-structured interviews (Saunders, Lewis and Thornhill 2009, 320) were conducted with three SDOs from three different banks that participated in the programme. Prior to conducting the interviews, the SDOs interacted with the participants' line managers to obtain feedback on their behaviour in the workplace. One of the themes that emerged was that there was a positive impact on the lives of the participants and ultimately in the workplace. The verbatim evidence as indicated by SDO1 from the interviews includes, for example:

"Obviously, from the learners' perspective, we have seen an improvement in them and the institution sees this programme as a meaningful programme."

The second theme that emerged was that of skills acquired on the programme. There was an improvement in the way that employees interacted with the customers they served, as well as 
the way they interacted with their co-workers. According to SDO2:

"...she has improved on the level of conversation with the customers and her peers alike and the project management skill and marketing management skill was also enhanced in the individual."

The third theme was the positive change in the overall attitude of the participants. They exhibited a higher level of internal locus of control, illustrated positive self-management techniques and confidence in coping with potential conflicts in the workplace as explained by SDO1:

"So obviously the student has gained confidence in performing certain duties with little or no supervision. He is more patient, understanding, response time and willing to get actively involved. He is more confident in handling issues that occur."

The fourth theme was the appropriateness of the programme in the workplace. From the participants' feedback it was clear that the programme addressed the real knowledge needed by the branch managers in their daily work activities. It seems as if the knowledge and skills gained from the programme helped them to cope with the job demands pertaining to financial management, sales and marketing and project management. This is highlighted by SDO1:

"Yes, because as a branch manager you ultimately control the branch from beginning to end. From the sales aspect to the financials to the marketing to the staff, so the programme provides a good understanding of those disciplines. The project management module equips managers on how to launch a new product, all those modules, they will use daily, because the branches are run like small business, individual branches."

The last theme identified was how the programme contributed to the career development of the participants. It was evident that the programme empowered banking employees to become eligible for management positions; and therefore served as a stepping-stone for employees to progress from supervisory roles to management roles. According to SDO2:

"Promotion could definitely be a consideration. It's in the pipeline. Yes, promotion from a coordinator to a junior manager."

\section{Overall return on investment}

In the second part of the qualitative analysis, interviews were conducted with three Bankseta staff members who have worked with this management programme. Two of the interviewees are specialists in the development of the programme, while the third interviewee is a manager for learning programmes at the Bankseta. These interviews gauged the cost versus the benefits of the programme on the career development of the learners, as well as its impact on the organisation. The first theme that emerged was that the programme addresses a need in the 
sector. This need led to a rise in demand, forcing the Bankseta to offer multiple intakes during the course of one year. From the responses it emerged that demand for the programme comes from both the learners and the banking organisations as explained by SDO1:

"...there is a greater demand each year on year, so definitely there is a strong need."

The second theme that emerged was that the programme has had a positive effect on the organisation. SDO2 indicated that:

“...when we spoke to the actual banks from a Bankseta perspective, they were always very positive about the programme."

The third theme that emerged from the interview pertained to career growth. SDO3 felt that the programme contributed to the career growth of the participants:

"...in the bank a lot of the banking staff basically have Matric, entry-level four, then basically they go onto supervisory and a supervisor could be at an NQF Level 4, but now they've gone up another NQF Level, which is 5. So as far as career development is concerned, yes most definitely."

The last theme that emerged was around the people that benefited the most from the programme. All three interviewees (SDO1, SDO2, SDO3) felt that the participants from retail banking benefited the most. For example: "I think it is more retail banking. Retail banking definitely."

Generally, the management programme was perceived as being of a high standard by all the different parties that were interviewed. The students understood that the applied research assignment involved entering new learning territory, with different knowledge and skill competencies to be gained while completing these assessments. The motives to learn are a mix of intrinsic worth and self-development, including instrumental ones like career advancement. The CMD students were clearly career motivated but were encouraged to use the learning experience for personal development. All this amounted to a new learning experience.

\section{DISCUSSION}

\section{Summary of findings}

Using Kirkpatrick's four-level theoretical framework, this article aimed to highlight the contributions of a PHEI in South Africa to the South African HE landscape. In pursuit of improving, reconfiguring, building, adding, integrating and regenerating human capital in the banking sector, this management programme was introduced by the Bankseta and implemented by a PHEI in seven regions of the country. By evaluating the CMD programme, we sought to 
correct the apparent mistrust associated with PHEIs in South Africa. Consistent with the results from the quantitative phase, and complementary to the findings in the qualitative phase, it is evident that PHEIs are playing a vital role in promulgating WIL in South Africa. The PHEI that was contracted was able to use its ability to be agile to guarantee high pass rates, good customer service and small classes to achieve the aim of the programme, which is in line with the aim of DHET. Contrary to these views, Stander and Herman $(2017,221)$ argue that the management of Quality Assurance (QA) in HE globally remains deficient, especially in PHEIs in South Africa. They contend that PHEIs constantly struggle to find a balance between the bottom line, academic rigor and quality of the services provided. This may be due to the lack of audited and reliable data representing the nature of the PHE sector (CHE 2016). The management programme offered to these bank employees improved their quality of work, which speaks to the quality of the programme. Participants' feedback also indicated that they had a good experience while enrolled on the course. The skills that they acquired while on the programme increased their marketability, and they received recognition in the workplace (such as promotions and career advancements). Overall, the participants and the sponsor (Bankseta) had a positive experience. Not only did the students benefit from the programme and obtain a registered qualification on NQF Level 5, the organisations and the banking sector as a whole benefited.

\section{Limitations and future directions}

Given that this study focused on one programme offered in the banking sector, future research would benefit from exploring numerous programmes offered in different business sectors in South Africa. Additional insights on the theoretical framework used in this article reveal that the study could be enhanced if the model of training evaluation is relevant to the programme. Singh $(2013,33)$ argues that no single model can be used to measure all the requirements of the training programme. This is because different aspects of the training gain prominence as the training evolves. Future researchers might also consider gathering information from PHEIs on how they manage issues around funding, quality, programme design and capacity development as more objective measures of performance. Another limitation was that only one PHEI was examined. A more comprehensive study should include various training providers in different parts of South Africa.

\section{CONCLUSION}

Research examining the contribution of PHEIs in South Africa is critical. With globalisation and the upsurge of the information age, there has been a global increase in demand for HE, 
which has resulted in the creation of PHEIs; but little is known about the contributions these institutions make to curb the skill shortages in South Africa (Wait and Govender 2016, 281). This article demonstrated the importance of PHEIs and how they use their competitive advantage of being agile to provide learning in the workplace. In comparison with public higher education institutions, private institutions have diversified their teaching methodologies to cater to the needs of regulatory bodies, such as the Bankseta. The business-like nature of PHEIs provides a platform from which they are client-oriented, focusing on delivering over and beyond the needs of the client. This atmosphere encourages innovation, diversification and attention to detail. All these attributes contribute to the success of the programme. The programme offerings at PHEIs are clustered around fewer disciplines than in public institutions, allowing for tailor-made programmes to meet the needs of corporate organisations; in this case, banks.

\section{REFERENCES}

Africa-America Institute. 2015. State of Education in Africa Report 2015: A report card on the progress, opportunities and challenges confronting the African education sector. http://www.aaionline.org/ wp-content/uploads/2015/09/AAI-SOE-report-2015-final.pdf (Accessed 07 October, 2017).

Badenhorst-Weiss, J. A., T. B. Landsberg, M. C. Cant, G. S. du Toit, R. Mpofu, S. Rudansky-Kloppers, R. Steenkamp, J. W. Strydom and M. Vrba. 2012. Introduction to Business Management. $8^{\text {th }}$ Edition. Southern Africa: Oxford University Press.

Baldry, K. 2016. Graduate unemployment in South Africa: Social inequalities reproduced. Journal of Education and Work 19(7): 788-812.

Bankseta. 2017. Enabling skills development in the banking and microfinance sector, 2017. www.bankseta.org.za/site.aspx (Accessed 13 June, 2017).

Baumgardt, J. 2013. "Quality assurance challenges for private providers in post-school education and training in South Africa". Doctorate of Education Thesis, University of South Africa, Pretoria.

Bernasconi, A. 2006. Does the affiliation of universities to external organizations foster diversity in private higher education? Chile in comparative perspective. Higher Education 52: 303-342.

Bezuidenhout, G. 2013. Factors that influence the choice of private higher education institutions by students. Master's Dissertation. Tshwane University of Technology, Pretoria.

Branson, N., M. Leibbrandt and T. L. Zuze. 2009. The demand of tertiary education in South Africa. Southern Africa Labour and Development Research Unit: 1-68.

Caerus Capital. 2017. The business of education in Africa. http://edafricareport.caeruscapital.co/ thebusinessofeducationinafrica.pdf (Accessed 4 September, 2017).

CHE see Council on Higher Education.

Council on Higher Education. 2013. The Higher Education Qualifications Sub-Framework. Pretoria: Council on Higher Education.

Council on Higher Education. 2016. South African higher education reviewed: Two decades of democracy. http://www.che.ac.za/sites/default/files/publications/CHE_South\%20African\%20 higher\%20education\%20reviewed\%20-\%20electronic_0.pdf (Accessed 13 May 2017).

Creswell, J. W. and V. L. Plano Clark. 2011. Designing and conducting mixed methods research. $2^{\text {nd }}$ Edition. United States of America: SAGE Publications. 
Davis, A. 2013. Exploring the strategizing practices of middle managers - a case study at a South African university. Doctorate in Commerce Thesis. University of South Africa, Pretoria.

Department of Higher Education and Training. 2013. Statistics on Post-School Education and Training in South Africa: 2014. http://www.dhet.gov.za/DHET\%20Statistics\%20Publication/Statistics\%20 on\%20Post-School\%20Education\%20and\%20Training\%20in\%20South\%20Africa\%202014.pdf (Accessed 25 May, 2017).

Department of Higher Education and Training. 2014. Statistics on Post-School Education and Training in South Africa: 2014. http://www.dhet.gov.za/DHET\%20Statistics\%20Publication/Statistics\%20 on\%20Post-School\%20Education\%20and\%20Training\%20in\%20South\%20Africa\%202014.pdf (Accessed 15 April 2017).

Department of Higher Education and Training. 2016a. Milestones 2009-2016. An Overview. http://www.dhet.gov.za/Publications/DHET\%20Milestones\%202009\%20-\%202016.pdf (Accessed 15 April, 2017).

Department of Higher Education and Training. 2016b. Register of Private Higher Education Institutions. http://www.dhet.gov.za/Registers_DocLib/REGISTER\%20OF\%20PRIVATE\%20 HIGHER\%20EDUCATION\%20INSTITUTIONS\%2013December\%2016.pdf (Accessed 23 April 2017).

DHET see Department of Higher Education and Training.

Dlamini, R. 2016. The Global Ranking Tournament: A dialectic analysis of Higher Education in South Africa. South African Journal of Higher Education 30(2): 53-72.

Dyer, J. A. 2003. Multidisciplinary, interdisciplinary, and transdisciplinary educational models and nursing education. Nursing Education Perspectives 24(4): 186-188.

Faber, T. and F. Collins. 2016. "Academics queuing to quit SA." Times LIVE. https://www.africanews hub.com/news/5748195-academics-queuing-to-quit-sa (Accessed 4 September 2017).

Field, C. and M. Shah. 2016. A global perspective on private higher education, xxi-xxvii. Cambridge, MA: Chandos.

Finn, W. 2013. "Private universities: An independent advantage." Independent, 16 August 2012. http://www.independent.co.uk/student/into-university/clearing/private-universities-an independent-advantage-8052821.html (Accessed 4 September 2017).

Hay, D. and M. Monnapula-Mapesela. 2009. South African higher education before and after 1994: A policy analysis perspective, in Higher education in South Africa: A scholarly look behind the scenes, edited by E. Bitzer. Stellenbosch: SUN Media.

HEQC see Higher Education Quality Council.

Higher Education Quality Council. 2004. Criteria for Institutional Audits. Pretoria: Council for Higher Education.

Kirkpatrick, D. 1996. Great ideas revisited. Training and Development 50(1): 54-59.

Kolb, A. K. 2015. Experiential learning. Experience as the source of learning and development. $2^{\text {nd }}$ Edition. New Jersey: Pearson Education

Laeeque, S. H., S. F. Babar and H. M. Ahmad. 2017. The integrative determinants of innovation performance: The role of learning organization and knowledge creation. Pakistan Journal of Commerce and Social Sciences 11(1): 166-183.

Luhn, A. 2016. The learning organisation. Creative \& Knowledge Society 6(1): 1-13.

Mohamedbhai, G. 2008. The effects of massification on higher education in Africa. Association of African Universities, February 2008, Mauritius.

Ngware, M. W. 2016. A critical assessment of "Higher education and economic development: The importance of building technological capabilities". International Perspectives on Education and Society 30: 201-219.

Nzimande, B. 2009. "Challenges facing the South African higher education system". 250th Seminar of the University of Johannesburg's Faculty of Humanities (Johannesburg), 2009. 
http://www.politicsweb.co.za/politicsweb/view/politicsweb/en/page71656?oid=139807 (Accessed 22 August, 2017).

Psacharopoulos, G. and H. A. Patrinos. 2002. Returns to investment in education: A further update. World Bank Policy Research Working Paper, 1-29.

Rajeev, P., M. S. Madan and K. Jayarajan. 2009. Revisiting Kirkpatrick's model - an evaluation of an academic training course. Current Science 96(2): 272-276.

SA News. 2016. "Universities face another crisis: Shortage of academics." University World News, 2016 http://www.universityworldnews.com/article.php?story=20161112192655570 (Accessed 04 September 2017).

Saunders, M., P. Lewis and A. Thornhill. 2009. Research methods for business students. $5^{\text {th }}$ Edition. London: Prentice Hall.

Setswe, G. 2013. Private higher education in Africa: The case of Monash South Africa. Africa Education Review 10(1): 97-110.

Singh, M. 2013. Training evaluation: Various approaches and applications. The IUP Journal of Soft Skills 7(1): 27-34.

Stander, E. and C. Herman. 2017. Barriers and challenges private higher education institutions face in the management of quality assurance in South Africa. South African Journal of Higher Education 31(5): 206-224.

Teixeira, P., V. Rocha, R. Biscaia and M. F. Cardoso. 2012. Myths, beliefs and realities: Public-private competition and program diversification in higher education. Journal of Economic Issues 46(3): 684-703.

Teixeira, P., S. Kim, P. Landoni and P. Gilani. 2017. Rethinking the public-private mix in higher education. Rotterdam: Sense Publishers

Van Schalkwyk, R. D. 2011. The impact of leadership practices on service quality in private higher education in South Africa. Master of Commerce Dissertation. University of South Africa, Pretoria.

Wait, M. and C. M. Govender. 2016. Multi-stakeholder work integrated learning model for higher education - A transdisciplinary approach. South African Journal of Higher Education 30(20): 279-293.

Wangenge-Ouma, G. 2012. Tuition fees and the challenge of making higher education a popular commodity in South Africa. Higher Education 64(6): 831-844.

World Bank Group. (Ed.). 2012. World development indicators 2012. World Bank Publications.

Zain, O. M, M. T. Jan and A. B. Ibrahim. 2013. Factors influencing students' decisions in choosing private institution of higher education in Malaysia: A structural equation modelling approach. Asian Academy of Management Journal 18(1): 75-90. 